\title{
Niilismo e crença no diálogo David Hume de Jacobi ${ }^{1}$
}

\author{
Luiz Fernando Barrére Martin \\ Universidade Federal do $A B C$ (UFABC)
}

\section{RESUMO}

Podemos afirmar de modo fundamental que a crítica de Jacobi à filosofia deriva de seu afastamento do sensível em direção à constituição de verdades cada vez mais abstratas e passíveis de demonstração. Com isso a filosofia apenas conseguiu gerar disputas a respeito do que ela seja, sem conseguir demonstrar qual posição filosófica deu conta da tarefa e que terminam por levar à perda de confiança no empreendimento, ou em outras palavras, levar ao ceticismo. Trata-se aqui de, sem desconsiderar a influência da filosofia do senso comum de Thomas Reid, além em certa medida também da influência de Hume, como Jacobi procura sair desse impasse a partir do modo como compreende a noção de crença.

\section{PALAVRAS-CHAVE}

Jacobi; Senso comum; Niilismo; Crença; Ceticismo.

\begin{abstract}
We may fundamentally declare that Jacobi's critique of philosophy derives from his withdrawal from the sensitive towards the constitution of increasingly abstract and demonstrable truths. In this way, philosophy has only managed to generate disputes about what it is, without being able to demonstrate what philosophical position realized its task and what finally lead to the loss of confidence in the enterprise, or in other words, lead to skepticism. It treats here, without disregarding the influence of Thomas Reid's common sense philosophy, and to some extent also on Hume's influence, as Jacobi seeks to get out of this impasse from the way he understands the notion of belief.
\end{abstract}

\section{KEY WORDS}

Jacobi; Common Sense; Nihilism; Belief; Skepticism.

${ }^{1}$ Artigo escrito com apoio do CNPq, edital Universal no 28/2018. 
Eu: Mas onde está meu Sexto Empirico? [...] Ele: Eu posso perguntar, por que o senhor está tão impaciente para consulta-lo? Eu: Uma passagem sobre o orientar-se — ou sobre a crença: como o senhor queira

$\mathrm{Na}$ introdução que Thomas Reid fez à sua obra Uma investigação acerca da mente humana com base nos princípios do senso comum (Reid, 2009), temos um diagnóstico quanto ao avanço e ao rigor na constituição de uma ciência das faculdades mentais em comparação com as ciências que, segundo Reid, "tem conexão mínima com a mente" (Ibid., p. II). Na constatação desse avanço e rigor, a balança é favorável apenas a estas últimas: quanto mais se compreende sua natureza e seu uso, também aquilo que nelas é defeituoso, melhor se pode aplicá-las e obter sucesso (Ibid.). Exemplo desse caráter bem-sucedido é o conhecimento da natureza por meio da observação e da experiência.

Para Reid, com respeito aos afazeres comuns da vida, temos uma propensão a elevar fatos e observaçóes particulares a regras gerais. Essa propensão constitui também o procedimento que torna possível "ser feita qualquer descoberta real em filosofia”. (Reid, 2009, p. I2) É por essa aproximação entre como nosso entendimento atua nos assuntos cotidianos e como atua na filosofia que Reid buscará identificar à investigação da natureza. O modelo filosófico por ele mencionado é Newton e suas regulae philosophandi, pois na filosofia newtoniana para haver conhecimento da natureza deve-se partir dos fatos observáveis em direção a uma forma que os unifique e explique $^{3}$ (Ibid.).

Em contraposição a essa filosofia bem-sucedida e segura, Reid apresenta as artes nobres, a saber, aquelas vinculadas apenas à mente, pois sua matéria fundamental é esse conteúdo espiritual. Neste domínio encontram-se o pintor, o poeta, o ator, o orador, o moralista e o político. Aqui a diversidade e a singularidade de procedimentos são a regra (Ibid., p. II). Vale aqui por analogia a imagem que Reid utiliza para descrever a linguagem dos filósofos: esta é adequada a um determinado sistema,

\footnotetext{
2 Jacobi, 2004, p. I4.

3 É a esse procedimento filosófico que Reid refere explicitamente a Newton e às suas Regulae Philosophandi que Hegel também aborda no parágrafo $7^{\circ}$ da Enciclopédia das Ciências Filosóficas (I830), a Ciência da Lógica, e como um modo específico de se fazer filosofia, certamente não o dele. Lá na Enciclopédia Hegel vai então apresentar esse filosofar calcado na experiência como um modo diferente daquele dos gregos, pois estes náo iam além de estabelecer abstraçóes. Esta outra maneira de filosofar, surgida na modernidade, trata de penetrar a matéria e extrair o universal e necessário daquilo que parece ser pura contingência. Essa formulação de leis universais se realiza tanto para a experiência daquilo que se dá na natureza quanto para a experiência do que vai além do natural, como, por exemplo, uma experiência histórica do direito. Hegel chega mesmo a lembrar que essa criação de leis mais gerais a partir da simples experiência é ainda predominante entre os ingleses e por essa via Newton ainda é considerado o seu maior filósofo. (Ver, Hegel, 1995, p. 46-47)
} 
assim como um casaco se adequa inteiramente ao homem para o qual é feito. Se fossemos comparar o que ocorre com as chamadas artes nobres em relação ao que se passa com o conhecimento da natureza, no caso daquelas artes não há como se obter uma lei geral, um princípio unificador. Sempre que se desenvolve uma linguagem, e não apenas filosófica, qualquer linguagem que seja pura e simplesmente fruto da cultura, é a liberdade que nela predomina. É esta mesma liberdade que pode, segundo Reid, causar prejuízos e interpretaçôes defeituosas (Ibid., p. I4). Ao invés de nos submetermos à autoridade da natureza, humildemente atentos ao que ela nos declara, (Ibid., p. I2) fazemos uso de nossa liberdade criadora e imaginativa. Por trás dessa atividade livre e criadora está presente o gênio. É ele que adultera a filosofia e a preenche com o erro e a falsa teoria. A genialidade para Reid é essa imaginação criativa que, nas suas elaboraçóes, nas suas invençóes, gera extravagâncias e fantasias, afastando-se sempre mais de qualquer perspectiva na qual solidez e uma boa fundação fossem os objetivos primordiais, se é que para ele isso fosse possível no âmbito estritamente mental (Ibid., p. I5). Reid denomina ainda esses fabricantes de fantasias de "construtores de castelos", que até possuiriam sua legitimidade no romance, ao passo que na filosofia, seria isso algo espúrio (Ibid., p. I6).

Existe uma falta de plausibilidade nas construçóes teóricas dos filósofos sobre o que não é da esfera da experiência sensível que torna difícil se convencer daquilo que eles propóem a esse respeito. Toda vez que um filósofo se dedica a investigar nossos pensamentos, nossas opinióes, nossa própria consciência, suas formulaçóes só nos trazem perplexidade e trevas. Um exemplo disso para Reid é o cogito cartesiano (Ibid.). Como alguém pode propor duvidar de sua própria existência? Haveria aí atuando um exercício imaginativo que somente nos aproxima de adquirir um desprezo pela filosofia. Além disso, se Descartes de fato desconfiou de sua existência, nem a razão nem a filosofia poderiam lhe socorrer: "um homem que duvida (disbelieves) de sua própria existência, é seguramente tão incapaz de ser persuadido quanto um homem que acredita ser feito de vidro" (Ibid.).

Náo é o que acontece na esfera do conhecimento da natureza. Aqui se mitiga ou certamente se anula por completo essa falta de terreno firme que seria própria de especulaçóes filosóficas acerca da mente e de suas faculdades. Nas ciências que possuem a experiência sensível como ponto de partida de suas teorias, o acúmulo de conhecimentos é palpável. O estabelecimento de leis gerais confirma esse ganho e afasta possíveis disputas ou conflitos em torno desses conhecimentos. ${ }^{4}$

${ }^{4}$ No início dos Ensaios acerca das faculdades intelectuais do homem (doravante citado como Ensaios), Reid, a propósito de um comentário referente ao avanço do conhecimento e à ambiguidade das palavras, reafirma não apenas esse avanço da ciência da natureza, mas também o avanço da matemática. Em ambos os casos a constituição de um por assim dizer vocabulário aceito por essas comunidades científicas, um acordo quanto 
Reid chega mesmo a reconhecer a possibilidade de progresso, uma vez que a cada conhecimento adquirido outros podem ser acrescentados. A única hipótese de uma reviravolta completa no conhecimento da natureza somente adviria de uma mudança de seu curso. (Ibid.) O cientista, diferentemente do filósofo, não se perde em discussões que no limite levem a, nos termos de Reid, delírios como os de Descartes. O mesmo se passa com os "pobres mortais ignorantes" (poor untaught mortals), (Ibid., p. I8) isto é, aqueles que não adquiriram cultura letrada. Estes não duvidam daquilo que veem e nem daquilo que os cerca, quer sejam coisas quer outros indivíduos com os quais se relacionam. Aquilo que temos diante de nós está dado e não se pode, por exemplo, dizer que não sinto o calor do sol que me aquece ou que não estou conversando com um amigo que está sentado na cadeira à minha frente. Mas os filósofos não se satisfazem com tais crenças (beliefs) ${ }^{5}$ imediatas, eles lastimam a credulidade do comum dos mortais e então buscam dar razóes, provas, para as crenças que comumente possuímos, como se isso fosse necessário e alcançável. Entre crer nas fantasmagorias filosóficas ou crer naquilo que nos é dado na vida comum, Reid é taxativo: "eu desprezo a filosofia e renuncio à sua orientação, que possa minha alma permanecer com o senso comum" ${ }^{6}$ (Ibid.).

É pela via da falta de apego ao senso comum que Reid despreza o cético. De fato, o que lhe incomoda mais é o que ele considera a insustentabilidade da postura cética. Entre Hume se afirmar como cético e efetivamente viver de acordo com essa postura filosófica, existe, para Reid, uma distância que nunca é superada. Suas açôes não iriam de fato corresponder às suas palavras:

$\mathrm{Na}$ verdade, ele engenhosamente reconhece que foi somente na solidáo e isolado que ele poderia dar algum assentimento à sua própria filosofia; mas so-

\footnotetext{
aos termos que utilizam — suas definiçóes e axiomas — impediu que continuassem as disputas em torno ao que seria o caminho mais consistente para o desenvolvimento dessas ciências. Infelizmente, nota Reid, não ocorreu esse acordo no que respeita às faculdades e operaçóes da mente. (Cf. Reid, 2002, p. I8ss)

5 Para se referir às crenças que temos em nossa vida, Reid tanto utiliza o termo faith quanto belief. À primeira vista, pareceria necessário que o filósofo fizesse uma distinção quanto ao uso desses termos. Comumente fé (faith) é um termo que estaria mais próximo de um uso religioso: tenho fé em Deus. Mas Reid se serve de faith e belief como termos sinônimos para crença em geral. Nesse sentido a fé religiosa seria mais uma espécie de crença.

6 Nos Ensaios, Reid dedica uma seção específica a discutir o significado de senso comum. Fundamentalmente, a compreensão de senso comum de Reid diz respeito a uma certa concepção de sensatez difundida entre os homens. Um homem dotado de senso comum é um homem sensato (a man of sense). Na linguagem comum, continua o filósofo, se concede que alguém de bom senso é alguém capaz de julgar bem. Não posso negar que há uma mesa diante de mim. Só o insensato o faria. Este seria aquele que não é dotado daquele "grau de julgamento que é comum aos homens com os quais podemos conversar ou realizar negócios". (Ver Reid, 2002, p. 424)
} 
ciedade, assim como a luz do dia, dissiparam a escuridão e a névoa do ceticismo, e o fizeram se entregar ao domínio do senso comum (Common Sense)" (Ibid., p. 20).

Tal como Hume, também Pirro de Eléia não assumiria integralmente o seu ceticismo. Quanto a este último, considerado patrono do que posteriormente foi designada como escola cética pirrônica, seria, portanto, difícil imaginar, de acordo com a interpretação de Reid, que ele seguisse tão ferreamente sua "doutrina” a ponto de colocar constantemente sua vida em risco. A se seguir, continua Reid, os relatos apresentados por Diógenes Laércio com base no testemunho de Antígono de Caristo, por não poder crer em nada, Pirro não se moveria para se afastar de uma carroça que viesse em sua direçáo, ou de um cachorro que o atacasse ou ainda mesmo de continuar andando em direção a um precipício. Sua sorte é que havia sempre alguém, um amigo, não tão cético quanto ele, sempre pronto a impedir que ele sofresse algum dano (Ibid.). O fato é que, segundo Reid, seria inverossímil supor que Pirro, ou qualquer outro cético, fosse tão fiel a seus "princípios", que terminasse entâo abandonando qualquer possibilidade de crer em algo. E assim, por náo poder aderir integralmente à sua postura cética, por ser obrigado a tomar decisóes, fatalmente entraria em contradiçáo com sua filosofia.

É curioso que Reid chame de atrevimento filosófico rejeitar "princípios que irresistivelmente governam a crença e a conduta de toda humanidade no que respeita às preocupaçóes comuns da vida; e aos quais o filósofo tem de se entregar, após ter imaginado que os refutou" (Ibid., p. 2I). Nesse atrevimento estaria certamente contemplado o ceticismo de Pirro. A sua indiferença em relação a todas as coisas, ao que lhe pode ser um bem ou um mal, é aos olhos de Reid uma insensatez diante do que se apresenta a nós na vida cotidiana e que não pode ser evitado. Em certo sentido o juízo de Reid talvez não deixasse de ter sua razão, pois conforme o relato de Pierre Hadot a respeito de Pirro, a indiferença deste abrange uma falta de distinção entre as emoçóes, quanto àquilo que se considera habitualmente perigoso ou inofensivo, sobre o valor a atribuir a esta ou aquela pessoa, a este ou aquele lugar. Desta perspectiva, Pirro talvez não se detivesse em seu caminho em direção ao precipício. O que, entretanto, importa nessa descrição de Hadot é salientar a vigência do "princípio" cético "não mais isto que aquilo" 7 . A indiferença se origina dessa dificuldade

\footnotetext{
7 Nas Hipotiposes Pirrônicas Sexto Empírico comenta o significado dessa fórmula: "E a expressão 'Não mais isso do que aquilo' indica portanto nosso sentimento (páthos), pelo qual nós chegamos finalmente ao equilíbrio em virtude da equipolência dos objetos opostos (tôn antiqueiménon pragmáton); e por 'equipolência' (isosthéneian) nós queremos dizer igualdade com respeito ao que parece provável (pithanón) a nós, e por 'oposto' queremos dizer em geral contraditório, e por 'equilíbrio', recusa de assentimento a qualquer alternativa”. Cf. Sextus Empiricus, 2000, p. I09-III.
} 
em assentir a uma de duas hipóteses possíveis, uma vez dada a igual força entre elas. Quem afirma com ênfase uma posição, por exemplo, considera algo um mal e sofre demais por isso, atrai somente perturbaçáo para si. O indiferente, por outro lado, adquire uma tranquilidade interior, uma independência absoluta e ao fim ao cabo a virtude. Existe aqui uma consciência da debilidade humana e da dificuldade de se alcançar posiçóes definitivas acerca das coisas. Diante desse vazio da existência, Pirro busca atingir a tranquilidade por meio de um exercício constante de despojamento que, ao final, transforma seu modo de vida e além disso servirá de exemplo para outros $^{8}$. Hadot ainda cita um testemunho sobre o comportamento de Pirro feito por um discípulo, Fílon de Atenas: "Foge dos homens, não se preocupa com a vanglória e com as discussôes acirradas" 9 .

Parece, portanto, pela descrição de Pierre Hadot, que não haveria incompatibilidade entre a figura de Pirro, sua filosofia e uma atitude de aceitação daquilo que nosso senso comum nos incita a náo evitar. Nesse sentido, seria, à primeira vista, bastante plausível associar Pirro às observaçóes que Reid faz das diferenças entre os poderes vinculados ao nosso estado natural em distinção às faculdades que desenvolvemos pela cultura (Ibid., p. I2ss). Quanto a tais observaçóes, se o ser humano já tem nele por natureza as sementes do lógico, do gosto e da moral, tais faculdades ainda estão adormecidas no selvagem. A permanecer a humanidade neste estado, inexiste a possibilidade de que a degeneração e a corrupção da espécie aconteçam. O homem natural tem carências bastante rudimentares, é "como uma árvore na floresta, pura e simplesmente produção natural” (Ibid., p. I3). Com uma certa nuance por assim dizer rousseauísta, Reid tem no horizonte a ideia de que o desenvolvimento da cultura, por trazer ele próprio uma ampla diversidade de rumos imprevistos, torna incerto que esse desenvolvimento traga apenas benefícios para a humanidade. A natureza, em contrapartida, é, portanto, sinônimo de simplicidade e inocência. O cético, que segundo Hadot, estaria devotado ao exercício constante de uma atitude de indiferença em relaçáo às coisas, à busca de uma simplicidade perdida com o desenvolvimento dos poderes da mente, em suma, próximo da natureza, não teria para Reid, no entanto, essa simplicidade, dado que coloca em dúvida "os princípios que irresistivelmente governam a crença e a conduta de toda humanidade" (Ibid., p. 2I).

Com efeito, nada mais distante de Pirro e dos céticos pirrônicos, ou mesmo ainda de Hume, uma tal subversão de costumes e crenças em virtude da dificuldade de que possamos afirmar peremptoriamente alguma verdade. Uma vez que se torna

8 Cf. Hadot, 1999, p. 165-169 e, particularmente, p. I68-169.

9 Cf. Diógenes Laércio, Vidas e doutrinas dos filósofos apud Ibid., p. I69. 
difícil asserir algo acerca da realidade última das coisas, que a filosofia dogmática não é capaz de nos fazer decidir entre uma teoria e outra, o cético desistiria de qualquer crença? Passaria entáo a viver sem crenças? Pelo contrário, ele náo deixa de se orientar pelo que chama de regras normais da vida. ${ }^{10}$ Somos capazes de pensamento e sensação, desenvolvemos técnicas que nos permitem produzir objetos que nos auxiliam para a satisfação de nossas necessidades, seguimos leis e costumes, em suma, não podemos evitar de aceitar nossa inserção no mundo e os diferentes aspectos aí envolvidos (Sexto Empírico, 2000, p. 17). O cético, portanto, não é nada diferente em atitude daquela que Reid supóe que o cético justamente se recusa a aceitar, mas que, continua o filósofo escocês, ele reconheceria vez ou outra por não ter como ser tão rigoroso ao seguir sua filosofia delirante.

A despeito da pertinência ou não da leitura que Reid faz do ceticismo ao apontar incongruências entre a atitude filosófica do cético e o seu modo de vida, há um outro aspecto por ele comentado que merece consideração: diz respeito às filosofias que não possuem a natureza por base, mas antes concernem à "mente e suas faculdades" (Ibid., p. I6). Esse aspecto diz respeito ao impasse que nos levam todas essas tentativas filosóficas que põem em desconfiança os sentidos e as certezas mais comuns que podemos ter em nossas vidas. Elas começam pela tentativa de fundar os primeiros princípios da natureza humana a partir das ideias ou do eu. É o que ocorre com Descartes e Berkeley. No primeiro caso, a certeza a ser alcançada dependerá da dúvida dos sentidos e da própria existência. Ao final nos libertamos desse delírio com o Cogito, ergo sum (Ibid., p. I6). Já o bispo Berkeley advogaria em favor da descrença completa do mundo material e somente concordaria com a existência de espírito e ideias. A origem de tais posiçóes filosóficas em Berkeley adviria da incorporação de princípios difundidos pelas teorias de Descartes, Malebranche e Locke. A par dessas consideraçóes, poderíamos enfim resumir o argumento de Reid nos

${ }^{10}$ Victor Brochard, a propósito da exposição que faz da figura de Pirro e de sua atitude filosófica, retoma a descrição que dele faz Diógenes Laércio e que justamente insiste nessa conformidade de Pirro em relação às leis, costumes e religiáo de seu país (Brochard, 2009, p. 73). Vale citar aqui o trecho de Diógenes Laércio utilizado por Brochard e que vai na contramão da apresentação de Pirro e dos céticos como aqueles que, nos termos de Reid, se afastam dos princípios que governam irresistivelmente a crença e a conduta de toda humanidade: "Pois naquilo que depende de nós, nem sequer escolhemos isto ou vamos evitar aquilo. E tudo que não depende de nós, mas da necessidade, não podemos evitá-lo, como o passar fome e sede e sentir dor. Quando os dogmáticos dizem que o cético poderá viver sob a condição de não evitar, se receber tal ordem, de esquartejar seu pai, respondem os céticos que poderão viver abstendo-se das investigaçóes dos dogmáticos, mas não em questóes que se referem à vida e a sua conservação. De modo que escolhemos ou evitamos algo segundo a prática habitual, e nos atemos às leis." (Diógenes Laercio, 2008, p. 505). 
seguintes termos: a descrença nos sentidos e na existência do mundo natural, feita por esses autores em prol da certeza e anterioridade das ideias e do domínio espiritual, só pode mesmo levar ao ceticismo.

Se há um domínio onde reina a confusão e a disputa, a dificuldade em chegar a algo de seguro e consistente, é o espiritual, pois neste o que comumente encontramos é o exercício de uma liberdade imaginativa que apenas propicia uma profusão de ideias extravagantes em cada filosofia originada. E a filosofia de Hume, abertamente professando o ceticismo em relação tanto à natureza humana quanto à ciência, é mais um elemento impulsionador da constatação da falta de substância das especulaçôes desses filósofos e da consequente descrença cética em relação às mesmas $^{11}$. O resultado que então surge dessas meditaçôes filosóficas é o de nos afastar das sensaçôes e do mundo no qual vivemos em favor de abstraçóes que nos deixam na mais completa incerteza a respeito de tudo ${ }^{12}$. O nome que Jacobi, influenciado pela crítica de Reid à filosofia, dará a esse estado de coisas que parece levar a um "desaparecimento" do mundo que desde sempre estamos inseridos será niilismo. O objetivo primordial deste texto é, portanto, compreender, levando em consideração a influência de Thomas Reid, e em certa medida também a de David Hume, não apenas o desenvolvimento da crítica de Jacobi às filosofias chamadas de idealistas, mas também a constituição que ele empreende de uma perspectiva filosófica calcada na noção de crença (Glaube).

\footnotetext{
${ }^{11}$ Ainda a respeito da filosofia de Hume, ou mais precisamente, de seu ceticismo e da consequente impossibilidade dele derivada com relação a um conhecimento demonstrativo, uma vez que não nos é possível escapar da mera probabilidade em todas as questóes, Reid assim se pronuncia: "No tratado da natureza humana, livro I, parte 4, seção I, o autor encarrega-se de provar dois pontos: primeiro, que tudo o que é chamado de conhecimento humano (significando conhecimento demonstrativo) é apenas probabilidade; e, segundo, que essa probabilidade, quando devidamente examinada, dissipa-se gradativamente, e por fim não deixa nenhuma evidência: de modo que, nessa questão, não há motivo para acreditar em qualquer proposição antes do que na sua contrária, $\mathrm{e}$ 'todos aqueles que argumentam ou creem em qualquer coisa são certamente tolos' (Hume, 1978, p. 270) apud Reid, 2002, p. 562.

${ }^{12}$ Ainda sobre o caráter abstrato e enganador da filosofia, Günther Baum nos lembra que o libelo de Reid contra o "abstracionismo" filosófico toma como ponto inicial dessa história a filosofia de Platáo. Começa na alegoria da caverna, pela qual Platão ensina que na intuição de objetos perceptíveis sensíveis somente podemos perceber sombras. Esse desprezo em relaçáo ao sensível começaria entáo com Platáo e viria até Hume, visto que nós não perceberíamos objetos exteriores imediatamente, mas antes somente representaçôes em nosso espírito. Há dois mil anos os filósofos esclarecem o processo de conhecimento por meio da atividade abstracionante do entendimento. Nesse processo de abstração, a representação (Vorstellung) refere-se às coisas em si tal como as sombras em relação às ideias platônicas. O que é objeto da percepção filosófica não são os objetos imediatos da percepção, mas sim as sombras (i.e., a representaçáo), e não o objeto real e sendo em si. O filósofo lida apenas com phantasma ou species. Cf. Baum, 1969, p. 42-44.
} 


\section{Niilismo e crença em Jacobi}

Segundo a descrição de Manfred Kuehn acerca da difusão da filosofia de Reid e seus seguidores na França e na Alemanha, (Kuehn, 1987, 52ss) as resenhas sobre as obras de Reid, Oswald e Beattie começaram a aparecer nesses países imediatamente após a primeira publicaçáo das mesmas em inglês. Assim, no mesmo de ano aparecimento de Uma investigação acerca da mente humana, o ano de 1764, o Journal Encyclopédique publicou em dezembro um resumo da obra no qual o autor chamava a atençáo para a crítica de Reid à "teoria das ideias" e sugerindo que se tratava de um importante trabalho e merecedor de estudo mais cuidadoso. Também o Journal de Trévoux, março de 1765 , menciona ser o principal objetivo do filósofo o combate tanto ao ceticismo quanto a Berkeley e "um autor moderno" que escreveu um livro intitulado "Traité de la Nature humaine", publicado em I739. A Bibliothèque des sciences et des beaux arts traz uma resenha crítica da Investigação em I767, um ano antes da tradução francesa da obra. O já citado Journal Encyclopédique publica ainda em 1768 uma resenha favorável à tradução recém surgida. $\mathrm{O}$ fato fundamental a ser notado é que desde 1768 já era disponível em língua francesa a obra de Reid e facilmente acessível para os filósofos alemães.

Mesmo na Alemanha, já em I4 de junho de I764 se noticiava o aparecimento do Inquiry de Reid no Neue Zeitungen von gelehrten Sachen de Leipzig. Também aqui o tom geral é elogioso ${ }^{13}$.

No mesmo espírito elogioso, todavia mais crítico, se publica em 6 de março de I769 no Göttingische Anzeigen uma resenha crítica da obra de James Oswald An Appeal to Common Sense in Behalf of Religion, surgida em dois volumes em I766 e I772. Por fim, outro seguidor de Reid, o filósofo James Beattie tem sua obra de I770, An Essay on the Nature and Immutability of Truth in Opposition to Sophistry and Scepticism, resenhada já em I77I também no Göttingische Anzeigen. ${ }^{14}$ Aqui também o elogio é temperado com críticas, no entanto, as mesmas estão longe de serem francamente hostis à obra.

Dessa exposição de Kuehn, o balanço geral é de que, mesmo com críticas, há na Alemanha um interesse vivo pelas obras desses autores críticos da filosofia e do ceticismo. De fato, dos anos setenta do século dezoito até pelo menos a Crítica da

\footnotetext{
${ }^{13}$ Reid é apresentado nos seguintes termos: "erudito e perspicaz autor que, no belo trabalho aqui anunciado tentou refutar o sistema irracional dos céticos de uma maneira meticulosa, e em defender com muitas provas novas e incontroversas a certeza da cognição que nós obtemos pela mediação dos sentidos externos. Ele especialmente contesta o Tratado da Natureza Humana [sic], aparecido pela primeira vez em 1739 e contendo a defesa mais evidente do ceticismo." in: Neue Zeitungen von gelehrten Sachen, I4 de junho de 1764, p. 377-78, particularmente, p. 377 apud Kuehn, 1987, p. 53.

${ }^{14}$ Göttingische Anzeigen, I77I, no ${ }^{\mathrm{I} 2}$ (28 de janeiro), p. 91-96 apud Ibid., p. 57.
} 
Razão Pura ${ }^{15}$, o trio escocês teve notoriedade como inimigos do ceticismo e do idealismo. E esse interesse pelo ponto de vista crítico desses autores em relação à filosofia certamente náo passou despercebido de Jacobi, assim como de seu amigo Hamann e de um filósofo como Herder ${ }^{16}$.

Apesar da influência patente da filosofia do senso comum na Alemanha a partir da década de setenta do século dezoito, poder-se-ia à primeira vista contestar essa mesma influência, uma vez que Jacobi refere-se a niilismo e os escoceses não se valem dessa terminologia. Com efeito, o termo niilismo adquire uma abrangência e reconhecimento no século XIX como uma perda de sentido geral da existência na vida moderna. Nesse movimento, também o mundo metafísico é descoberto como uma pura invenção. E se o termo, pelo menos neste último caso, ainda evoca uma crítica das fantasias filosóficas, ele não terá em Jacobi essa extensão adquirida posteriormente. Conforme a descriçáo de Günther Baum, Jacobi foi o primeiro a empregar o termo "niilismo" na filosofia. O termo lhe chama a atençáo quando do estudo da história da filosofia medieval a partir do manual de Johann Andreas Cramer (continuador de Bossuet), publicado em I786. Lá ele encontra o termo "nihilianismus" referido a Petrus Lombardus e Petrus von Poitier como inculpados da "heresia do nihilianismus" (Baum, I969, p. 44ss).

Quanto à aproximação do termo niilismo em Jacobi da crítica severa de Reid às filosofias idealistas e mesmo ao ceticismo do autor do Tratado da Natureza Humana, ela se faz a partir da crítica jacobiana da razão e do modo como se dá sua preeminência em relação ao entendimento. No prefácio e introdução aos seus escritos filosóficos completos e publicados em I8I5, (Jacobi, 2004, p. 373-432), Jacobi indica como ponto de partida dessa preeminência da razão a filosofia de Aristóteles. (Ibid., p. 378-379) Nesta ocorre inicialmente a subordinaçáo do conhecimento imediato (die unmittelbare Erkenntnis) ao conhecimento mediato. Aristóteles submeteu a faculdade da percepção — que tudo fundamenta - à faculdade da reflexão. Nos termos de Jacobi, subordinou o arquétipo à cópia, a essência à palavra, a razáo ao entendimento. (Ibid., p. 379) Nesse movimento em direção à mediação, passa a ter validade como verdadeiro somente o demonstrável e sujeito a provas. Mas por que a razão,

${ }^{15}$ Com a publicação da Crítica da Razão Pura há uma virada na recepção da filosofia escocesa do senso comum, isto é, da direção da crítica desses autores a Hume e ao idealismo passar agora para a crítica da filosofia kantiana. Mas se Jacobi e Enesidemo-Schulze se postam entáo contra Kant, Vieweg atenta ainda que, no caso de Hegel, o viés é de crítica ao senso comum devido a uma adoção da perspectiva kantiana. Ver, Vieweg, I999, p. 53 ss.

${ }^{16}$ Cf. Kuehn, I987, cap. VIII. 
como nota Jacobi, "naquele [o entendimento] pode soçobrar (untergehen) e desaparecer"? (Ibid.) Isto ocorre em virtude dela perder sua capacidade de pressupor o verdadeiro, o bom e o belo em si, e além disso, capacidade que não surge sem estar acompanhada da exigência de afastar do nome de "razáo" da mera faculdade dos conceitos, julgamentos e silogismos. Em outras palavras, tudo que a razão pode alcançar não se faz por intermédio de deduçôes silogísticas, próprias ao que Jacobi chama de entendimento. (Ibid., p. 378)

Desde Aristóteles, muitos foram os que colocaram a sensibilidade na base do entendimento para, então, tentar por meio de abstraçóes elevá-la ao suprassensível, isto é, à razão, para por fim se apoderar do verdadeiro em si. Esta foi a causa da, segundo Jacobi, confusão babilônica da linguagem na filosofia (Ibid., p. 38I). Estaria presente nessa concepção de razão filosófica a possibilidade de uma passagem contínua do sensível ao suprassensível. A história da filosofia desde Aristóteles atesta esse processo de abstração que vai até Kant, quando então este demonstrou incontroversamente a impossibilidade de se ir além dos fenômenos (Erscheinungen) e de se obter um conhecimento do suprassensível (Ibid.). É digno, portanto, de crédito, reconhece Jacobi, o ataque kantiano contra a metafísica que busca dar um caráter de conhecimento às suas especulaçóes suprassensíveis, entretanto o que o idealismo transcendental permite surgir em seu lugar são as aspiraçóes práticas da razão, ou o retorno sub-reptício da velha metafísica por meio de uma crença (Glauben) que prepondere sobre os sentidos, o entendimento e sobre a própria razão (Ibid., p. 38I382). Além disso, a crítica kantiana purifica os sentidos a ponto de fazê-los perder a propriedade de serem uma faculdade perceptiva. Desse modo, há, para Jacobi, uma total vacuidade dos sentidos de acordo com a caracterização e limites da sensibilidade na Crítica da Razão Pura.

A crítica kantiana, seja ainda notado, conduz ao niilismo, (Ibid., p. 382) pois nessa relação do entendimento com a sensibilidade estabelecida na Crítica da Razão Pura não há lugar para um saber verdadeiro e objetivo. Ficamos no "abismo sem fundo de uma absoluta subjetividade" (Ibid.). De modo irônico, assim resume Jacobi sua posição em relação a Kant: por amor à ciência Kant solapa a metafísica, o que é um mérito, por outro lado, por amor à metafísica, com a elevação da crença — racional — acima do saber, ele solapa a ciência. (Ibid., p. 394ss) Em outras palavras, o que Kant, por conseguinte, de modo acertado dá com uma mão, logo a seguir ele retira com a outra.

Em Kant há o que para Jacobi impede o saber objetivo, a saber, representaçóes. Estas têm sua origem no nosso entendimento e são válidas apenas para nós e para nossa sensibilidade humana. Não é possível um saber do suprassensível, contudo Kant nos apresenta um saber objetivo que somente atinge formas subjetivas a partir 
de intuiçóes subjetivas (Ibid., p. 6I). Ora, a objetividade, da perspectiva jacobiana, se faz pelo testemunho dos sentidos acerca das coisas exteriores. Os sentidos nos fornecem a certeza do que está aí diante de nós como um fato. A palavra mais adequada para Jacobi aqui é revelaçâo (Offenbarung $)^{17}$. Se digo que há uma mesa à minha frente, não se trata de uma sensação de algo a ser encontrado apenas em mim, na minha representação, mas sim digo que se trata de um ser independente de nós e por nós percebido (wahrgenommen). Ele está ali a nossa frente e não necessita de provas para que se perceba a existência da coisa (Ibid., p. 32ss). A objetividade náo é um mero fenômeno como suporia Kant. A coisa em si mesma está diante de nós: "eu experiencio que eu sou e que algo fora mim é no mesmo instante indiviso" (Ibid., p. 37). Entre mim e o objeto não existe uma representação discursiva mediadora. Jacobi se vale de Hume para explicitar essa imediatez do contato com o objeto e que nos permite ter crença no mesmo ${ }^{18}$. Entre a ficçâa e a crença (belief), observa Hume, a crença é acompanhada de um sentimento que não depende de nossa vontade, ou seja, náo temos a liberdade de conjecturar a respeito dessa crença, se algo é digno de crença ou não. Ela se impõe a nós. O objeto é uma revelação. Mas em que sentido isso poderia ser dito? É no sentido simples de algo que se mostra a nós que Jacobi se vale do termo. Algo se revela a nós pelos sentidos (Ibid., p. 3I). Até aqui há acordo com Hume. $\mathrm{O}$ acordo cessa na medida em que Hume permanece, segundo Jacobi, em suspenso quanto à crença ser sobre o real ou o supostamente real. Daí a diferença entre o que Jacobi denomina de realista decidido, isto é, aquele que indubitavelmente aceita as coisas exteriores pelo testemunho dos sentidos, e o idealista cético, que náo é capaz de decididamente afirmar se realmente percebe coisas exteriores a nós (Cf. Ibid.). Além de Hume, que mesmo com ressalvas Jacobi menciona em seu favor para explicitar sua concepção de crença, Reid também não é por ele esquecido. Quando declara expressamente que só podemos acreditar naquilo que não é capaz de nos fornecer prova rigorosa, é a Reid que se refere. (Cf. Ibid., p. 2I). A noção de crença de Reid aparece explicitada nos seus Ensaios acerca das faculdades intelectuais do homem no momento em que discute o significado de percepção. Assim, perceber um objeto externo sensível é um ato de nossa mente que depende de se ter uma noção mais ou menos distinta do objeto percebido, além de uma convicção irresistível e crença (belief) de sua existência (Reid, 2002, p. 97). A preocupação de Reid aqui é, portanto, a de assinalar que na percepção não surgem dúvidas em

\footnotetext{
${ }^{17}$ Sobre o poder revelador da percepção, ver também o artigo de George di Giovanni "Hume, Jacobi and common sense. An episode in the reception of Hume in Germany at the time of Kant. Cf. Giovanni, I998, particularmente a p. 48 .

${ }^{18}$ Sobre o que será dito doravante, Jacobi cita de Hume $A$ investigação concernente ao entendimento humano, seção $\mathrm{V}$, parte II.
} 
relação ao que percebo. Por isso ele também acrescentará como elemento da noção de percepção o seu caráter imediato. Não há como fugir ou evitar a evidência que a mim se apresenta. Sua imediatez é o que justamente dela afasta todo raciocínio ou argumentação. Que eu veja, para usar o exemplo de Reid, com maior distinção um objeto a grande distância em um dia claro do que em um dia nebuloso, é algo que não posso evitar quando a mim essa situação se configura. Mas poderia ser questionado: qual o critério para essa crença imediata e irresistível? O que cauciona essa crença é o senso comum (common sense). Aqueles dotados de senso comum não teráo dúvidas quanto a ver um objeto distante com maior nitidez em um dia claro do que em um dia nebuloso. Só não conseguirão alcançar a mesma evidência os lunáticos, aqueles que foram persuadidos por coisas que parecem contradizer o claro testemunho de seus sentidos, aqueles que, por exemplo, acreditam seriamente que são feitos de vidro (Ibid., p. 98). O senso comum é, por conseguinte, associado ao que Reid denomina de condição saudável (sound state), condição que diz respeito simultaneamente à mente e aos corpos afastados de "estranhas doenças", que justamente dificultam o exercício de uma percepção distinta dos objetos pelos sentidos.

Em resumo, é a partir dessa crença que irresistivelmente a nós se impóe que Jacobi, na esteira de Reid e, guardadas as devidas proporçóes, também de Hume, vai se contrapor ao cético e ao dogmático. $\mathrm{O}$ cético é aquele que tenta sustentar uma atitude filosófica que, ao fim ao cabo, torna vacilantes todas as crenças. Já o dogmático seria aquele que não tem como convencer demonstrativamente alguém daquilo que propóe como teoria, uma vez que ela não tem o amparo da realidade, nunca deixa de abandonar o âmbito das representações mentais subjetivas. Jacobi compara o filósofo idealista, que também pode aqui ser chamado de dogmático, a um sonâmbulo, a alguém que é incapaz de acordar, pois em oposição a isso, entra sim num sono mais e mais profundo, cada vez menos próximo da realidade (Jacobi, 2004, p. 7I). O caminho entrevisto para não se permanecer duvidando de tudo e nem especular da maneira a mais fantasiosa para sustentar verdades, é o caminho em que são admitidas crenças ancoradas na realidade, crenças que por sua vez revelam os objetos imediatamente. A partir do que foi exposto, podemos então agora compreender o significado da citação de Pascal que Jacobi coloca como epígrafe de seu David Hume, afinal, a ele se revela uma verdade que não necessita de provas, algo que, é o que ele pretende, o afasta simultaneamente das disputas entre os dogmáticos, e da dúvida irrestrita dos céticos ${ }^{19}$.

\footnotetext{
${ }^{19}$ A citação de Pascal é a seguinte: "A natureza confunde os pirrônicos e a razão confunde os dogmáticos. Nós temos uma incapacidade de provar, invencível a todo dogmatismo. Nós temos uma ideia da verdade, invencível a todo pirronismo." Cf. Jacobi, 2004, p. 8.
} 


\section{Referências Bibliográficas:}

Baum, G. (1969). Vernunft und Erkenntnis - Die Philosophie F.H.Jacobis. Bonn: H. Bouvier Verlag.

Brochard, V. (2009). Os céticos gregos. Tradução de Jaimir Conte. São Paulo: Odysseus Editora.

Di Giovanni, G. (1998). Hume, Jacobi and Common Sense. An Episode in the Reception of Hume in Germany at the Time of Kant. Kant-Studien, I(89), p. 44-58.

Diógenes L. (2008). Vidas de los filósofos ilustres. Tradução, introdução e notas de Carlos García Gual. Madri: Alianza Editorial.

Hegel, G. W. F. (1995). Enciclopédia das Ciências Filosóficas em compêndio (I830), I - A Ciência da Lógica. Traduçáo por Paulo Meneses com a colaboraçáo do Pe. José Machado. São Paulo: Ediçóes Loyola.

Hume, D. (1978). A Treatise of Human Nature. L.A. Selby-Bigge e P.H.Nidditch (ed.). $2^{\mathrm{a}}$ ed. Oxford: Clarendon Press.

Jacobi, F. H. (2004). David Hume über den Glauben oder Idealismus und Realismus. In: Schriften zum Transzendentalen Idealismus. Unter Mitarbeit von Catia Goretzki, herausgegeben von Walter Jaeschke und Irmgard-Maria Piske. Hamburg/Stuttgart: FelixMeiner/Frommann-Holzboog

Jacobi, F. H. (2004). Vorrede, zugleich Einleitung in des Verfassers sämmtliche philosophische Schriften. In: Schriften zum Transzendentalen Idealismus. Unter Mitarbeit von Catia Goretzki, herausgegeben von Walter Jaeschke und Irmgard-Maria Piske. Hamburg/Stuttgart: FelixMeiner/Frommann-Holzboog.

Jacobi, F. H. (2016) The Main Philosophical Writings and the Novel Alwill. Tradução, introdução, notas e bibliografia por George di Giovanni. Montreal: McGillQueen's University Press.

Kuehn, M. (1987). Scottish Common Sense in Germany, I768-I800, A Contribution to the History of Critical Philosophy. Kingston/Montreal: McGill-Queen's University Press.

Reid, T. (2000). An Inquiry into the Human Mind on the Principles of Common Sense. Editado por Derek R. Brookes. Pennsylvania: Pennsylvania University Press.

Reid, T. (2002). Essays on the intellectual powers of man. Editado por Derek R. Brookes. Edinburgh: Edinburgh University Press.

Sextus Empiricus (2000). Outlines of Pyrrhonism. Tradução por R. G. Bury. Cambridge, Massachusets/London, England: Harvard University Press.

Vieweg, K. (1999). Die Philosophie des Remis - Der junge Hegel und das 'Gespenst des Skepticismus'. München: Wilhelm Fink Verlag, I999. 